\title{
RANCANGAN APLIKASI MANAJEMEN DOKUMEN TENDER BERBASIS WEB PADA PT. EMI
}

\author{
Sablin Yusuf \\ Jurusan Teknik Informatika, Fakultas Ilmu Komputer, Bina Nusantara University \\ Jln. K.H. Syahdan No. 9, Kemanggisan, Palmerah, Jakarta 11480 \\ sablin@binus.edu
}

\begin{abstract}
The objective of this researh is to design a software application for bidding document management as required by PT Energy Management Indonesia (EMI) in order to increase the company performance. The methodology used is fact-finding through direct observation, followed by literature study, and web application development method using waterfall model and rapid prototyping for software development. The result is a software application, web based, which can increase the company performance due to the required bidding document preparation and the responding data are well stored and managed hence can be accessed easily when needed. In summary the application which is well supported by the related database will assist the company quikly and easily in bidding preparation process
\end{abstract}

Keywords: application design, waterfall model, database, bidding document, PT. EMI

\begin{abstract}
ABSTRAK
Tujuan dari penelitian ini adalah untuk merancang aplikasi manajemen dokumen tender yang sesuai dengan kebutuhan perusahaan PT. Energy Management Indonesia (EMI), sehingga dapat membantu meningkatkan kinerja perusahaan. Metodologi penelitian yang digunakan adalah metode penemuan fakta yang dilakukan dengan observasi langsung ke lapangan, dilanjutkan dengan studi kepustakaan, dan metode perancangan aplikasi web dengan menggunakan metode waterfall dan rapid prototyping. Hasil yang dicapai adalah terbentuknya suatu aplikasi manajemen dokumen tender yang berbasis web yang dapat meningkatkan kinerja perusahaan karena pengerjaan dokumen yang dibutuhkan untuk suatu lelang proyek dan data yang dibutuhkan telah tersimpan dengan teratur sehingga bisa dengan mudah didapatkan ketika dibutuhkan oleh pihak perusahaan. Simpulan dari penelitian ini adalah dengan adanya aplikasi manajemen dokumen tender yang didukung oleh basis data yang baik dapat mempermudah dan mempercepat perusahaan dalam proses penyiapan mengikuti suatu tender.
\end{abstract}

Kata kunci: perancangan aplikasi, waterfall model, basis data, dokumen tender, PT. EMI 


\section{PENDAHULUAN}

Seiring dengan perkembangan teknologi yang semakin maju, kebutuhan untuk mendapatkan informasi dengan cepat dan mudah juga semakin meningkat. Begitu pula dengan akses pengerjaan sebuah tender. Banyak sekali kesalahan yang dilakukan oleh setiap perusahaan dalam pengerjaan sebuah tender sehingga tingkat kegagalan suatu tender menjadi besar. Kesalahan ini yang melatar belakangi penelitian ini.

PT. EMI (Energy Management Indonesia) adalah sebuah perusahaan yang bergerak dibidang konsultan energi milik negara yang memerlukan sebuah aplikasi yang dapat mengatur setiap pengerjaan dokumen tender yang ada untuk mempermudah pengerjaan sebuah tender serta meminimalisasi human error pada pengerjaan sebuah tender baik dari berkas-berkas Rencana Kerja dan Syarat yang selanjutnya akan disebut sebagai RKS pada masa prakualifikasi dan tender, tenaga ahli dan kelengkapannya, profil pengalaman perusahaan hingga peralatan yang tersedia pada perusahaan tersebut. Faktor-faktor utama yang menyebabkan perusahaan tersebut gagal tender ialah adanya kesalahan pada pengerjaan dokumen proyek, pemilihan tenaga ahli yang terlalu lama, kelengkapan dokumen seperti peralatan, pengalaman perusahaan, dan pekerjaan yang sedang dikerjakan seringkali salah format dikarenakan oleh waktu yang ada hanya sedikit sedangkan proyek yang ingin di ikuti banyak dan bersamaan waktunya.

Tujuan dari penelitian ini adalah menghasilkan suatu sistem aplikasi perangkat lunak untuk manajemen yang dapat menstrukturisasi segala keperluan di dalam pengerjaan sebuah rencana kerja dan syarat sebuah proyek. Pada sistem manajemen tersebut akan dapat me-record semua lelang proyek yang diikuti oleh perusahaan tersebut. Ruang lingkup aplikasi pada penelitian ini dibatasi pada pengerjaan berkas-berkas RKS untuk syarat pengerjaan pra-kualifikasi, validasi pemilihan tenaga ahli, pengerjaan berkas-berkas syarat tender, pengalaman pekerjaan pada PT.EMI (Energy Management Indonesia), dan data peralatan pada PT.EMI.

\section{METODE}

Metodologi penelitian yang digunakan dalam penelitian ini adalah studi lapang dan studi pustaka. Sedangkan metode yang digunakan untuk mengembangkan aplikasi perangkat lunak mengacu kepada model siklus pengembangan sistem klasik waterfall (Pressman, 2001) seperti dapat dilihat pada gambar 1, yang tahapannya terdiri dari system engineering, software requirement analysis, desain, koding, testing, dan maintenance.

\section{System Enginnering}

Dalam merancang sebuah perangkat lunak yang pertama harus dilakukan adalah mempelajari dan memahami semua elemen sistem yang diperlukan. Sistem merupakan hal yang penting dalam membuat sebuah perangkat lunak, karena perangkat lunak harus berhubungan langsung dengan elemen lainnya seperti perangkat keras, basis data dan manusia.

\section{Software Requirement Analysis}

Pada tahap ini dalam perancangan perangkat lunak, perlu mengetahui karakteristik dasar dari perangkat lunak yang akan dirancang, seperti fungsi, bentuk, dan tampilan dari perangkat lunak tersebut. 


\section{Design}

Untuk membuat suatu perangkat lunak perlu dirancang struktur datanya, arsitektur perangkat lunak, dan karakteristik tampilan yang akan disajikan.

\section{Coding}

Rancangan yang telah dibuat dalam tahap sebelumnya akan diterjemahkan ke dalam suatu bentuk atau bahasa yang dapat dibaca dan diterjemahkan oleh komputer untuk diolah.

\section{Testing}

Setelah tahap pengkodean selesai, dapat dilanjutkan ketahap pengujian (testing).Testing program dilakukan untuk mengetahui bila terjadi kesalahan pada program yang telah dibuat. Selain itu, dapat juga digunakan untuk memastikan apakah input proses dengan benar, sehingga dapat menghasilkan output yang sesuai.

\section{Maintenance}

Jika aplikasi tersebut telah sesuai, akan diberikan kepada pengguna, tetapi selama penggunaan tersebut akan terjadi penyesuaian atau perubahan sesuai dengan keadaan yang diinginkan, sehingga membutuhkan perubahan terhadap aplikasi tersebut.

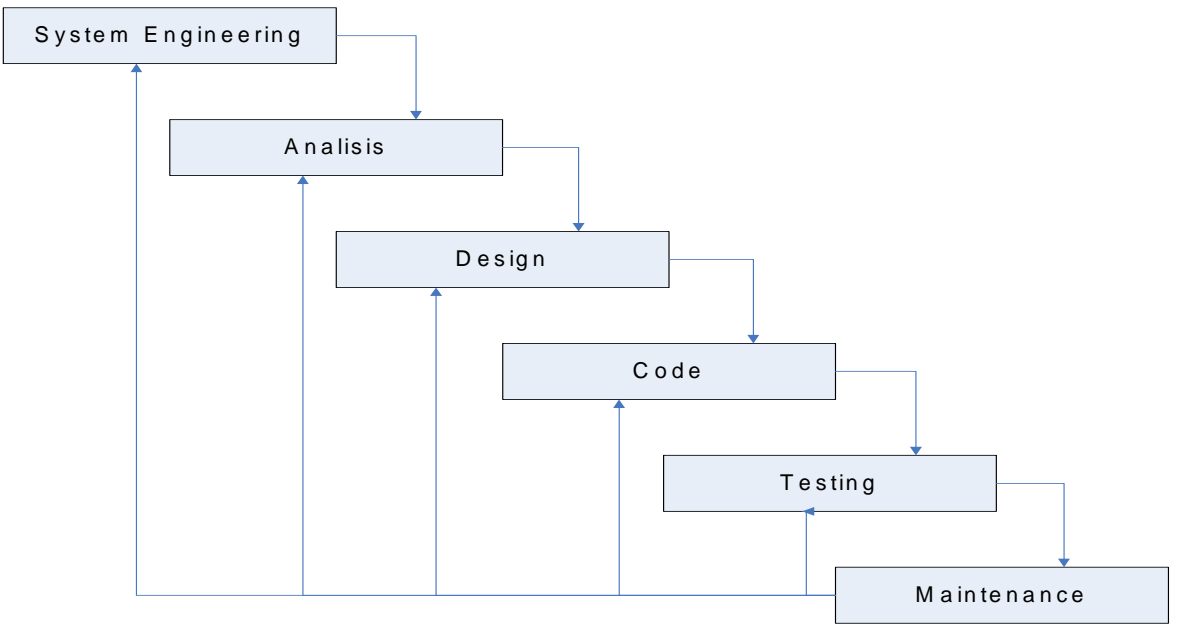

Gambar 1 Waterfall Model

\section{HASIL DAN PEMBAHASAN}

\section{Studi Pustaka}

Menurut Hall (2001), sistem adalah sekelompok dua atau lebih komponen-komponen yang saling berkaitan (interrelated) atau sublemen-sublemen yang bersatu untuk mencapai tujuan yang sama (common purpose). Sedangkan O'Brien (2004) menyatakan bahwa sistem informasi manajemen menghasilkan produk informasi yang mendukung dalam membuat keputusan bagi seorang manajer atau professional bisnis. Reports, displays dan responses dihasilkan oleh Sistem Informasi Manajemen dalam memberikan informasi yang spesifik yang dibutuhkan dalam membuat sebuah keputusan. 
Secara lebih spesifik Turban, Rainer \& Potter (2003) mengatakan bahwa Computer Based Information System adalah suatu sistem informasi yang menggunakan teknologi komputer dan telekomunikasi untuk melakukan suatu pekerjaan. Pengertian database menurut Connolly (2002) adalah "a shared collection of logically related data, and a description of this data, designed to meet the information needs of an organization” (p. 14).

Entity Relationship Diagram digunakan untuk menggambarkan struktur logikal database dalam bentuk diagram. ERD menyediakan cara yang sederhana dan mudah untuk memahami berbagai komponen dalam desain database (Connolly, 2002). ERD mempunyai tiga komponen yaitu entity, relationship dan properti.

Rekayasa Perangkat Lunak (Software Engineering) merupakan satu bidang profesi yang mendalami cara-cara pengembangan perangkat lunak termasuk pembuatan, pemeliharaan, manajemen organisasi pengembangan perangkat lunak dan sebagainya. Rekayasa perangkat lunak adalah penetapan dan penggunaan prinsip-prinsip perancangan dalam usaha untuk mendapatkan sebuah perangkat lunak yang ekonomis serta dapat diandalkan dan dapat bekerja secara efisien pada mesin yang sebenarnya (Pressman, 2001).

Dalam merancang suatu aplikasi, perlu diadakan pendekatan sistematis dalam perancangan perangkat lunak tersebut. Dalam rekayasa perangkat lunak terdapat sebuah pendekatan yang digunakan yang disebut dengan The Linear Sequential Model, atau terkadang disebut dengan Waterfall Model atau Classic Life Cycle Model (Pressman, 2001). Dalam merancang sebuah sistem aplikasi perangkat lunak diperlukan suatu kajian yang mendalam tentang bagaimana suatu sistem dapat berjalan sebagaimana mestinya. Terutama hubungannya dengan manusia yang akan menggunakan sistem itu nantinya. Oleh karena itu interaksi antara manusia dan komputer merupakan hal yang cukup penting dalam suatu perancangan sistem aplikasi. Interaksi manusia dan komputer adalah ilmu yang berhubungan dengan perancangan, evaluasi, dan implementasi sistem komputer interaktif untuk digunakan oleh manusia, serta studi fenomena-fenomena besar yang berhubungan dengannya (Shneiderman, 1998). Jadi interaksi manusia dan komputer merupakan dasar yang harus digunakan dalam perancangan suatu sistem komputer.

Delapan aturan emas perancangan dialog ini merupakan prinsip-prinsip dasar perancangan antarmuka yang paling banyak digunakan dalam pembuatan suatu sistem yang interaktif. Menurut Shneiderman (1998), aturan-aturan dasar ini adalah (1) rancangan yang dibuat harus selalu konsisten; (2) memungkinkan pemakai menggunakan shortcurts; (3) memberikan umpan balik yang informatif; (4) merancang dialog untuk menghasilkan keadaan akhir yang baik; (5) memberikan penanganan kesalahan yang sederhana; (6) mengizinkan pembalikan aksi (undo) dengan mudah; (7) mendukung pengaturan fokus secara internal; (8) mengurangi beban ingatan jangka pendek.

\section{Sistem Berjalan}

PT. Energy Management Indonesia (Persero) atau dulu dikenal sebagai PT. Koneba (Persero) didirikan pada tahun 1987, adalah badan usaha milik negara yang bergerak dalam bidang konservasi dan manajemen energi. Dari tahun ke tahun PT. EMI banyak membantu pihak pemerintah, BUMN dan swasta dalam kegiatan konservasi energi, manajemen energi dan diversifikasi energi. Pelaksanaan kegiatan usaha PT. EMI dilakukan oleh tenaga-tenaga terlatih yang profesional dibidangnya serta didukung peralatan-peralatan yang memadai sesuai kebutuhan. Akumulasi pengalaman PT. EMI diberbagai sektor di masyarakat dan di industri banyak memberikan nilai tambah dalam implementasi usaha PT. EMI melaksanakan tugas-tugas konservasi, manajemen dan diversifikasi energi.

Kini dengan pengalaman perusahaan yang sangat beragam pada bidang energi dan di dukung oleh tenaga-tenaga professional dan berpengalaman di bidang pengelolaan energi, perekayasaan, 
survey dan inspeksi serta pengelolaan risiko di berbagai sektor (Industri, transportasi dan bangunan), PT. EMI siap menjawab tantangan energi di Indonesia. Pada saat ini sistem yang berjalan pada PT. EMI dalam mempersiapkan dokumen-dokumen untuk mengikuti lelang tender dan menyajikan laporan progres report masih berjalan manual. Data dari para instansi yang melakukan pengadaan pun tidak tersusun dengan rapih, hanya berdasarkan dari arsip dokumen lelang yang pernah diikuti. Dokumen-dokumen yang dibutuhkan antara lain, berkas-berkas Rencana Kerja dan Syarat (RKS), data tenaga ahli, pengalaman perusahaan, peralatan serta pekerjaan yang sedang berlangsung.

Dalam pembuatan RKS, para admin proyek meniru dari data RKS sebelumnya yang masih ada dan disesuaikan dengan kebutuhan dari proyek yang akan diikuti. Format penulisan dari RKS yang sebelumnya ini menjadi dasar dari pembuatan RKS yang kemudian file ini disimpan kembali pada komputer atau flash disk, akan tetapi untuk penyimpanan file-file tersebut tidak terdapat tempat yang pasti. Kemudian untuk dokumen pengalaman perusahaan, terdapat file hasil dari sortiran arsip dokumen lelang yang pernah diikuti oleh PT. EMI. Penyortiran ini dilakukan setiap tahun secara manual kemudian disimpan dalam sebuah file excel.

Sehingga ketika para admin proyek membutuhkan data pengalaman perusahaan untuk penyusunan dokumen lelang, mereka dapat mengambil file sortiran tersebut. Akan tetapi, untuk penyimpanan file sortiran tersebut belum mempunyai tempat yang pasti. Dalam pembuatan dokumen pekerjaan yang sedang berlangsung hampir sama dengan pembuatan dokumen pengalaman perusahaan, hanya saja penyortiran dilakukan ketika pembuatan dokumen saja, arsip yang disortir merupakan dokumen-dokumen lelang yang proyeknya sedang dikerjakan oleh PT. EMI.

Untuk pengambilan data peralatan, para admin proyek mendapat data peralatan dari bagian teknis yang berada dibawah divisi Personalia dan Umum. Pendataan dari data peralatan yang sedang berjalan sekarang walaupun sudah menggunakan komputer, tetapi untuk penyimpaanannya belum ada tempat yang pasti. Sedangkan penyusunan dokumen tenaga ahli, para admin proyek mendapat data tenaga ahli dari bagian HRD yang berada dibawah divisi Personalia dan Umum.

Data yang didapat berupa CV dari para tenaga ahli dan daftar tenaga ahli beserta ceklist kelengkapannya. Kelengkapan yang dimaksud ialah ijazah, spt, npwp, bukti setor serta ktp. Dalam memeriksa kelengkapan dari tenaga ahli, HRD melakukanya dengan cara manual yaitu, tenaga ahli yang sudah memiliki kelengkapan maka pada bagian kelengkapannya diberikan ceklist, kemudian data ini disimpan dalam bentuk kertas. Kelengkapan-kelengkapan di atas merupakan salah satu syarat untuk tenaga ahli yang akan diikut sertakan dalam sebuah proyek.

Dari daftar tenaga ahli tersebut, para admin proyek membandingkan dengan dokumen tenaga ahli dari proyek yang sedang diikuti oleh PT. EMI. Apabila seorang tenaga ahli sedang diikutsertakan pada sebuah proyek pada instansi yang sama, maka tenaga ahli tersebut tidak boleh diikutsertakan kembali pada lelang proyek yang akan diikuti. Pengecekan ini dilakukan secara manual sehingga memakan waktu yang lama.

Pembuatan laporan dilakukan setiap bulan secara manual dengan cara, mengumpulkan keseluruhan berkas - berkas lelang proyek kemudian berkas - berkas tersebut direkapitulasi. Kegiatan ini dilakukan oleh divisi Personalia dan Umum. Laporan ini berisi daftar seluruh lelang proyek yang pernah diikuti atau sedang diikuti oleh PT. EMI baik yang gagal maupun yang berhasil. Hasil dari laporan kemudian diberikan kepada Direktur berbentuk dokuman kertas. Diagram arus dokumen (DAD) dari sistem yang berjalan dapat dilihat pada gambar 2 .

\section{Permasalahan}

Dari uraian sistem berjalan tersebut di atas dan pengamatan lapangan, maka dapat 
diidentifikasi permasalahan yang di hadapi oleh PT. EMI pada saat ini, yaitu penyimpanan atau pengelolaan data, penyimpanan dokumen tender, dan komunikasi data perusahaan di luar kantor.

\section{Penyimpanan atau Pengelolaan Data}

Dalam penyimpanan atau pengelolaan data, permasalahannya yaitu tidak adanya tempat penyimpanan data yang tetap untuk dokumen yang pernah ada; data tenaga ahli tercecer dan sering hilang; tidak adanya tempat penyimpanan data peralatan; dan tempat penyimpanan data instansi pengadaan tidak tersedia.

\section{Penyiapan Dokumen Tender}

Dalam penyimpanan dokumen tender, permasalahannya yaitu tidak adanya pengingat waktu pengumpulan dokumen prakualifikasi; tidak adanya format surat yang pasti pada setiap instansi; sulit mengecek tenaga ahli yang tersedia untuk suatu instansi untuk di jadikan tenaga ahli pada suatu tender yang baru; dan akurasi data dokumen yang di kerjakan oleh para admin proyek kurang baik dikarenakan oleh padatnya permintaan yang masuk sedangkan waktu yang tersedia terbatas.

\section{Komunikasi Data Perusahaan di Luar Kantor}

Dalam komunikasi data perusahaan di luar kantor, permasalahannya yaitu dewan direksi sering membutuhkan data laporan perusahaan diluar kantor dan laporan tersebut diperlukan oleh dewan direksi setiap saat. Namun pada saat ini penyiapan laporan membutuhkan waktu karena proses penyiapan masih manual dan proses penyiapan dokumen hanya dapat dilakukan di dalam kantor; dan perusahaan sedang akan mengembangkan adanya cabang didaerah lain. Sehingga nantinya pengerjaan persiapan RKS proyek akan dilakukan pada kantor cabang perusahaan di berbagai daerah sesuai dengan lokasi proyek.

Semua permasalahan yang di temukan dalam sistem yang berjalan tersebut di atas dapat mengakibatkan perusahaan kehilangan kesempatan meraih keuntungan dikarenakan oleh pengerjaan dokumen proyek dikerjakan dalam waktu yang relatif lama. Pengerjaan dokumen tender tersebut memakan waktu sekitar tujuh hari atau lebih. Sedangkan dalam perusahaan ini dapat mengikuti lebih dari satu proyek. Perusahaan akan kehilangan banyak peluang untuk meraih keuntungan dari pengerjaan proyek tersebut.

\section{Sistem yang Diusulkan}

Melihat permasalahan yang ditemukan di lapangan dan sangat mempengaruhi pengerjaan dokumen yang diperlukan dalam sebuah lelang pekerjaan, maka diusulkan sebuah aplikasi sistem berbasis web yang dapat mengurangi kendala-kendala yang ada dan dapat tersimpan secara terstruktur dan aman. Di dalam aplikasi sistem ini akan disediakan hal-hal yang di butuhkan untuk mengerjakan sebuah tender, antara lain aftar pengerjaan prakualifikasi beserta tanggal pengerjaan dan penanggung jawab; daftar tenaga ahli yang tersedia dalam pengerjaan suatu tender; daftar peralatan yang akan di cantumkan pada dokumen prakualifikasi; daftar pengalaman yang akan di cantumkan pada dokumen prakualifikasi; daftar pekerjaan yang sedang di kerjakan yang juga di lampirkan pada dokumen prakualifikasi.

Semua hal tersebut di atas sesuai dengan RKS yang ditentukan dalam setiap lelang pekerjaan. Apabila semua ketentuan yang ada didalam RKS tidak di penuhi maka akan mengurangi bobot sebuah peserta lelang. Didalam aplikasi yang diusulkan terdapat juga basis data dari PT.EMI tersebut. Didalam basis data tersebut terdapat data para pekerja yang berada dalam PT.EMI. Data Flow Diagram (DFD) dari aplikasi yang di usulkan dapat dilihat pada gambar 3 dan gambar 4. 

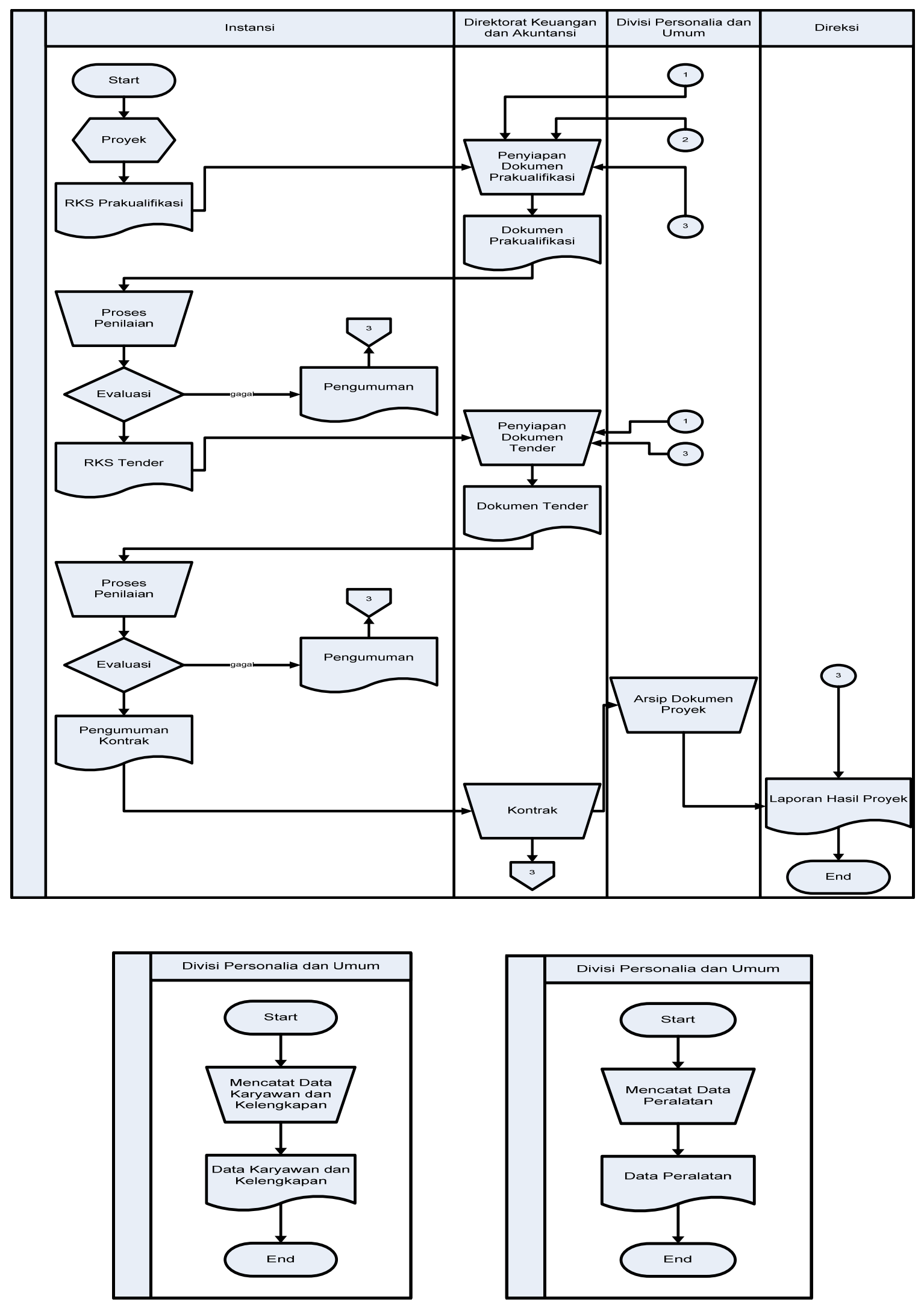

Gambar 2 DAD Sistem berjalan 


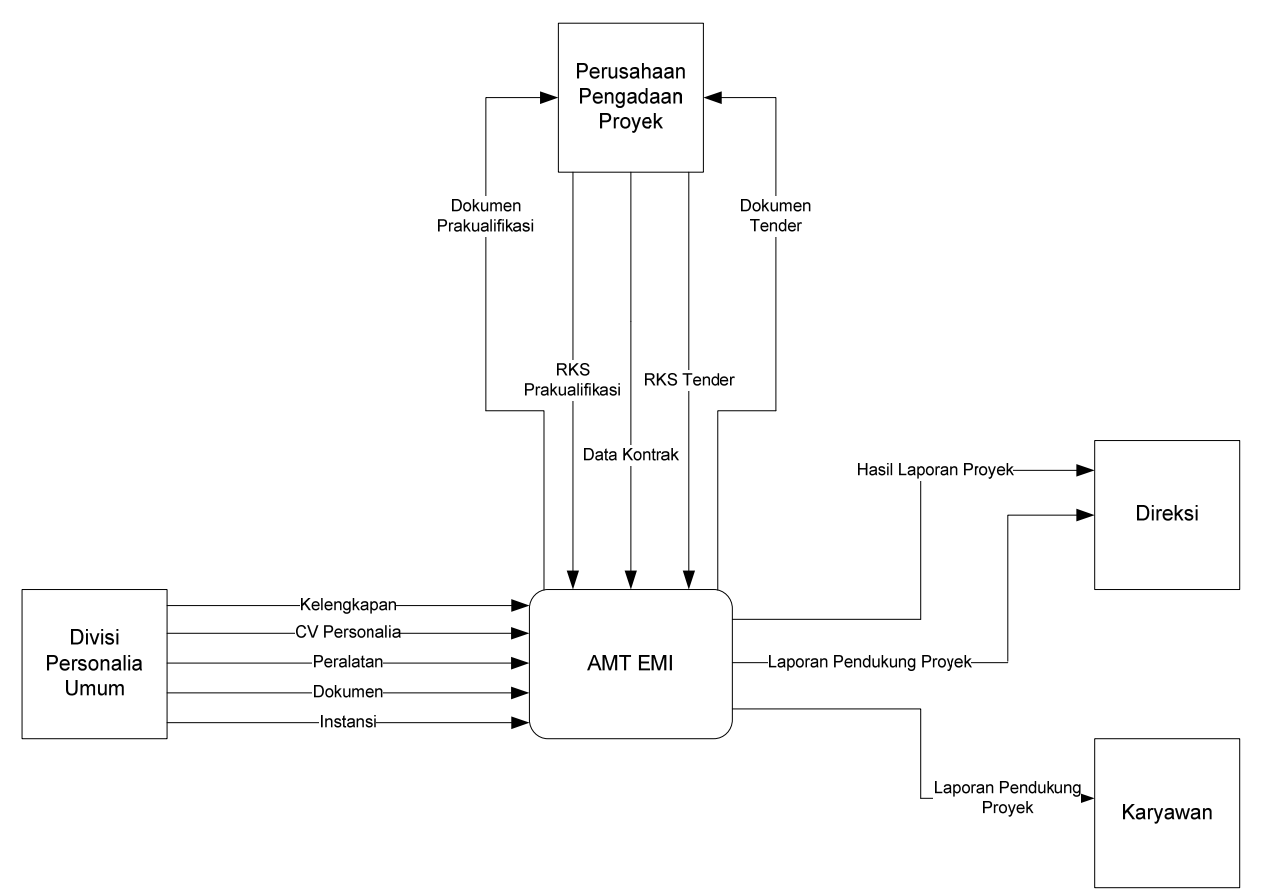

Gambar 3 Diagram konteks sistem yang diusulkan

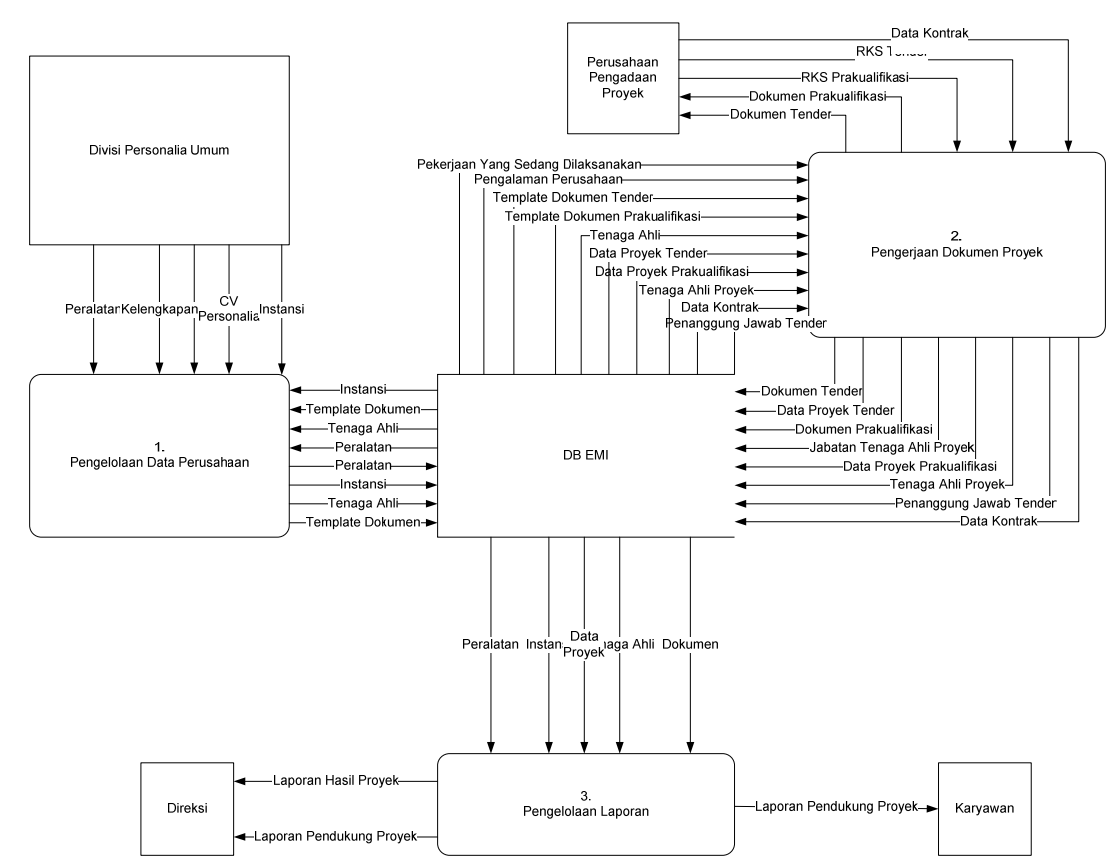

Gambar 4 Diagram nol system yang diusulkan

\section{Rancangan Aplikasi}

Rancangan aplikasi yang di ajukan untuk aplikasi ini bertujuan untuk memudahkan pengembang aplikasi untuk merealisasikan dan mengimplementasikan aplikasi. Rancangan aplikasi ini antara lain meliputi rancangan basis data, rancangan menu, rancangan layar, dan rancangan keamanan. Rancangan basis data yang berada di dalam aplikasi ini bertujuan untuk menyediakan basis 
data untuk menyimpan semua data yang ada didalam aplikasi. Entity Relationship Diagram (ERD) basis data tersebut dapat dilihat pada gambar 5. Di dalam aplikasi yang diusulkan terdapat menu-menu yang akan di akses oleh para user. Hierarki menu sistem yang diusulkan dapat dilihat pada gambar 6. Di dalam menu tesrsebut terdapat banyak layar antarmuka yang akan di akses oleh para user. Rancangan navigasi atau perpindahan dari satu layar ke layar lainnya digambarkan menggunakan state transition diagram (STD). Beberapa contoh STD tersebut dapat dilihat pada gambar 7 dan gambar 8. Dalam rancangan keamanan aplikasi ini pemakai aplikasi dibagi menjadi 3 jenis, yaitu admin, super user, dan user. Setiap user mendapatkan hak akses yang berbeda. Tetapi semua user dapat melihat semua data sesuai dengan hak aksesnya. Semua user harus login terlebih dahulu untuk dapat mengakses aplikasi ini.

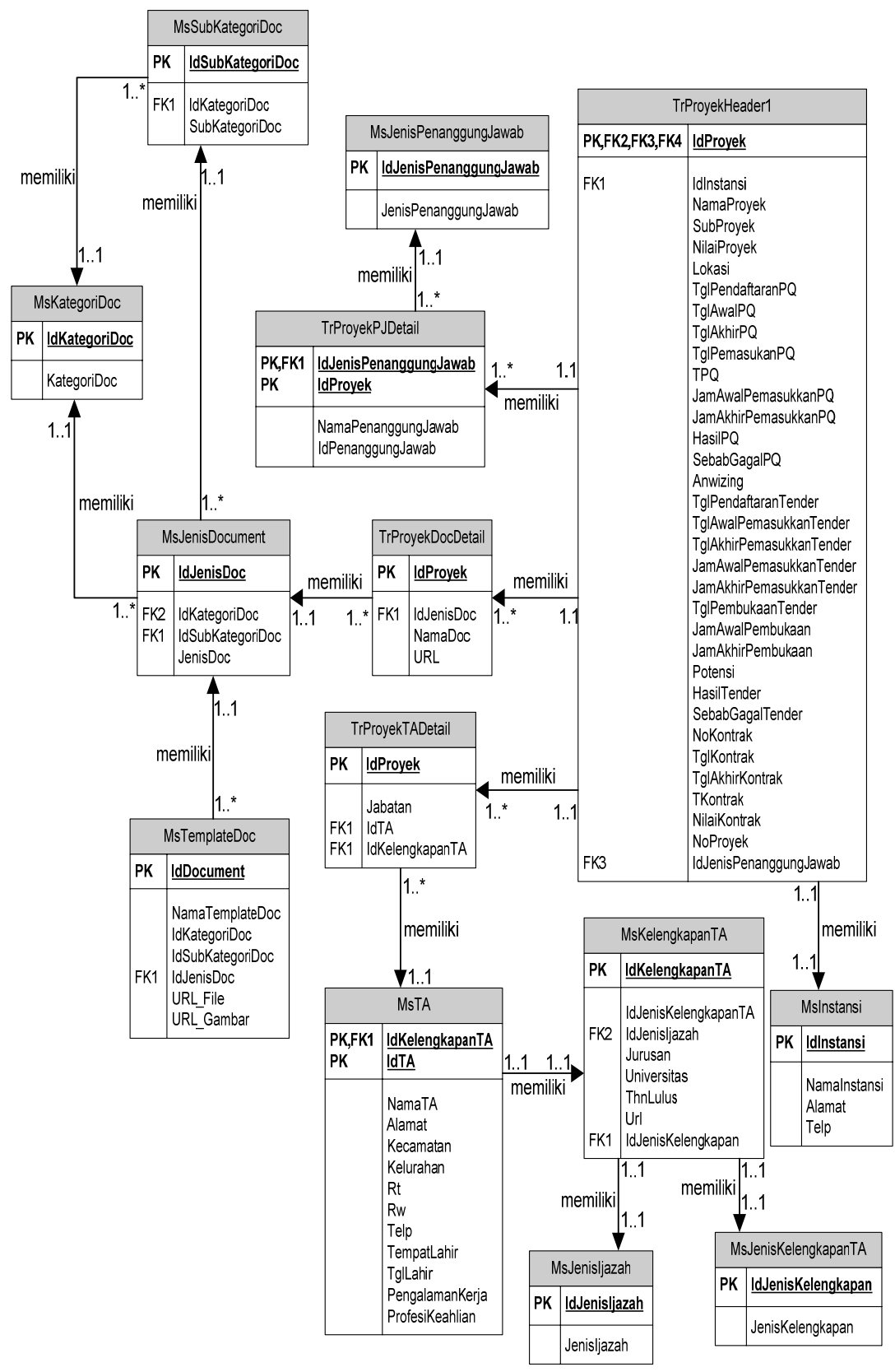

Gambar 5 ERD Database Aplikasi Manajemen Tender 


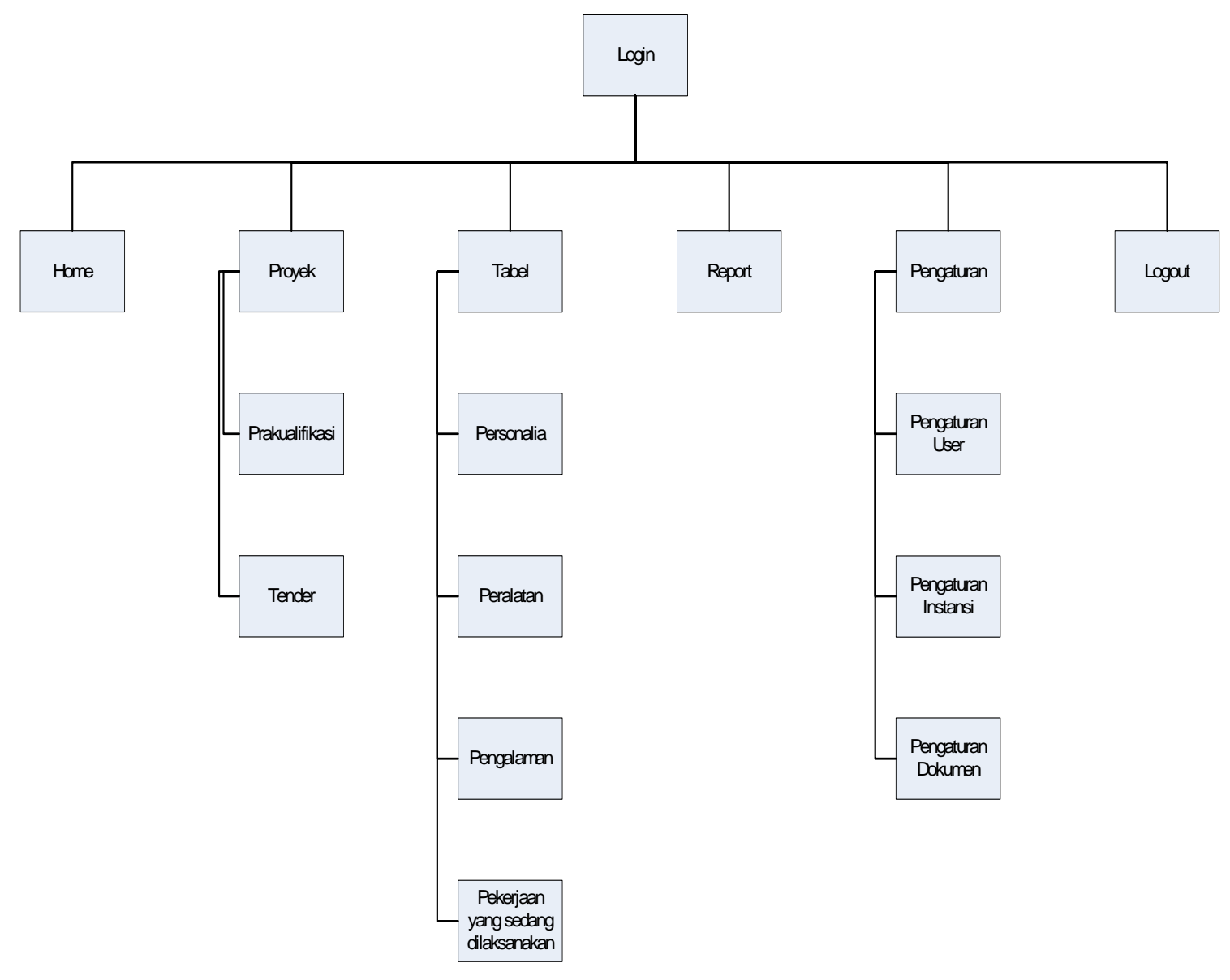

Gambar 6 Rancangan Menu Aplikasi

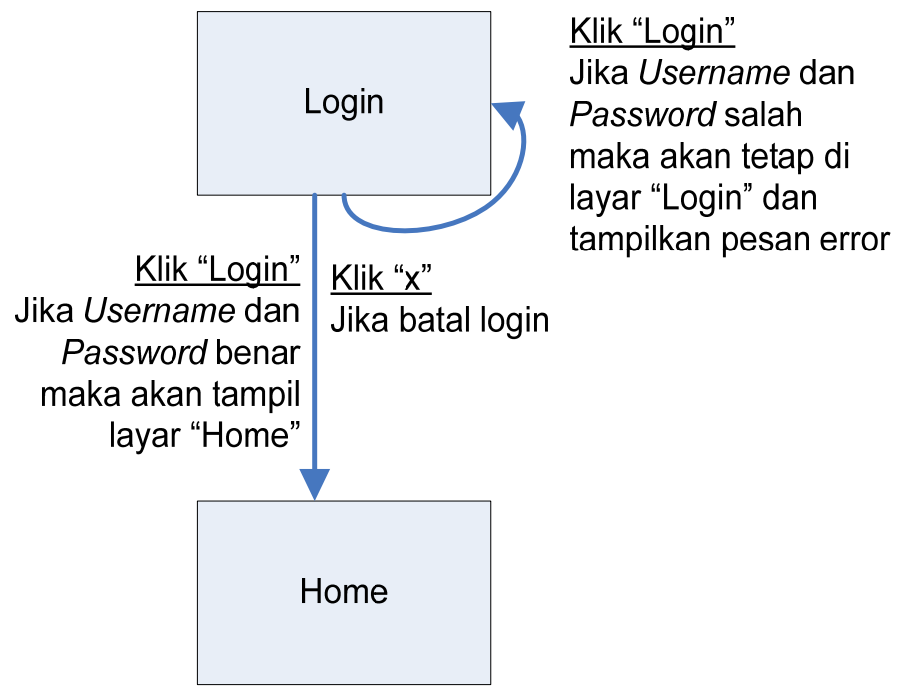

Gambar 7 State Transition Diagram Login 


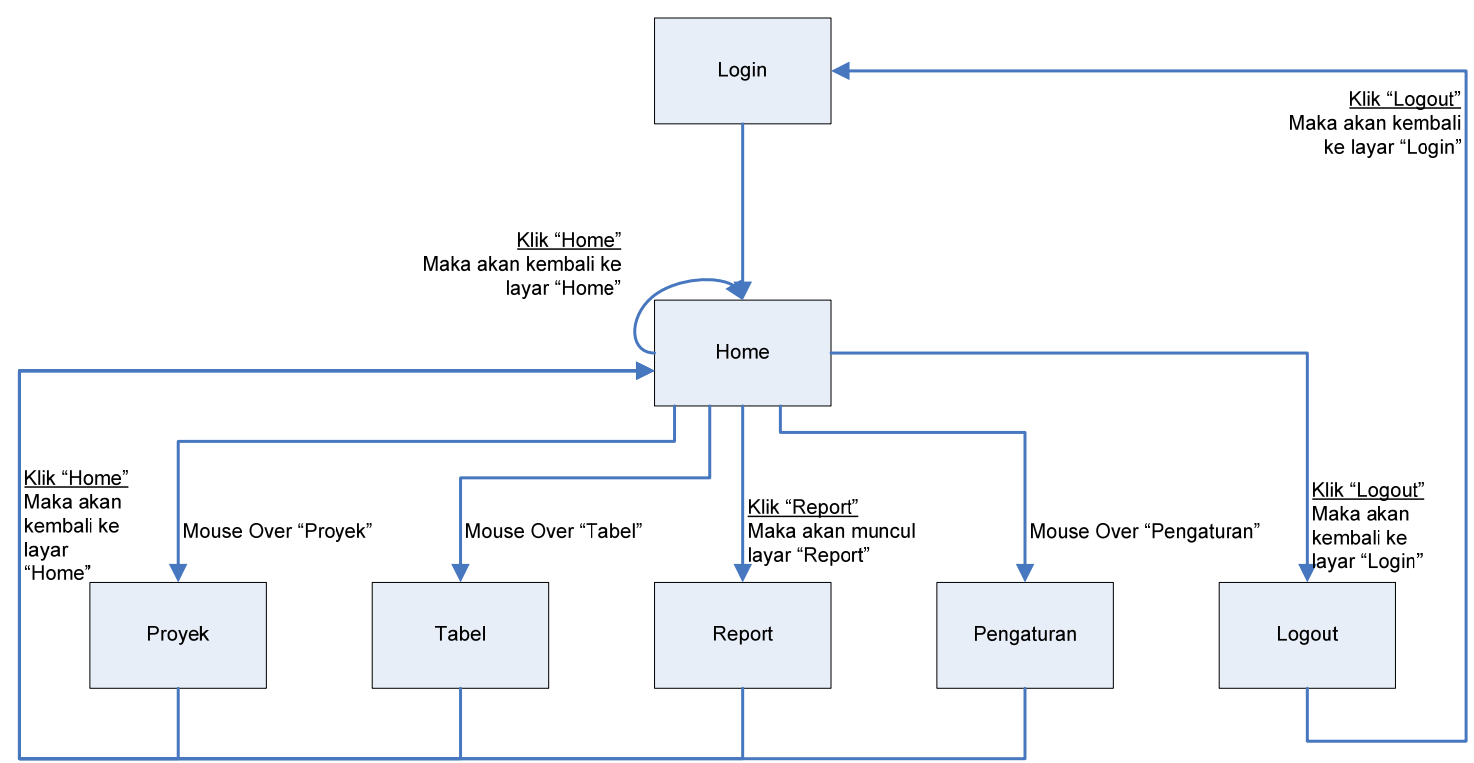

Gambar 8 State Transition Diagram Home

Admin memiliki hak akses pada manajemen data, contohnya input peralatan beserta editnya, input tenaga ahli beserta edit dan kelengkapan, serta manajemen user. Super User memiliki hak akses yang berbeda dengan admin. Super User adalah inti dari aplikasi ini. Super User yang hanya berhak mengerjakan proses pengerjaan dokumen tender tersebut. Hak akses dari Super User adalah input data proyek baru, pemilihan tenaga ahli yang sudah divalidasi sesuai dengan ketentuan, pengerjaan dokumen proyek mulai dari masa prakualifikasi sampai dengan kontrak, mengconvert data pengalaman perusahaan dan pekerjaan yang sedang dilaksanakan. User disini berbeda sekali dengan admin dan super user. User hanya memiliki hak akses untuk view data proyek, view data perusahaan, view progress report. Secara lengkap pengaturan hak akses dapat dilihat pada tabel 1 .

Tabel 1. Otoritas hak akses pengguna aplikasi

\begin{tabular}{lccccccccccccccccc}
\hline & \multicolumn{1}{c}{ Manajemen Data } & \multicolumn{1}{c}{ Pengerjaan Proyek } & Progress Report & \multicolumn{3}{c}{ Pengaturan } \\
USERS & $\mathrm{C}$ & $\mathrm{R}$ & $\mathrm{U}$ & $\mathrm{D}$ & $\mathrm{C}$ & $\mathrm{R}$ & $\mathrm{U}$ & $\mathrm{D}$ & $\mathrm{C}$ & $\mathrm{R}$ & $\mathrm{U}$ & $\mathrm{D}$ & $\mathrm{C}$ & $\mathrm{R}$ & $\mathrm{U}$ & $\mathrm{D}$ \\
\hline ADMIN & $\mathrm{Ya}$ & $\mathrm{Ya}$ & $\mathrm{Ya}$ & $\mathrm{Ya}$ & - & $\mathrm{Ya}$ & - & - & - & $\mathrm{Ya}$ & - & - & $\mathrm{Ya}$ & $\mathrm{Ya}$ & $\mathrm{Ya}$ & $\mathrm{Ya}$ \\
\hline SUPER USER & - & $\mathrm{Ya}$ & - & - & $\mathrm{Ya}$ & $\mathrm{Ya}$ & $\mathrm{Ya}$ & $\mathrm{Ya}$ & - & $\mathrm{Ya}$ & - & - & - & $\mathrm{Ya}$ & $\mathrm{Ya}$ & - \\
\hline USER & - & $\mathrm{Ya}$ & - & - & - & $\mathrm{Ya}$ & - & - & - & $\mathrm{Ya}$ & - & - & - & $\mathrm{Ya}$ & $\mathrm{Ya}$ & - \\
\hline
\end{tabular}

Keterangan:
$\mathrm{C}=$ Create
$\mathrm{U}=$ Update
$\mathrm{R}=$ Read
$\mathrm{D}=$ Delete

Data aplikasi sangat rawan akan kerusakan. Jadi pihak pengembang membuat rancangan back up dengan tujuan untuk menyelamatkan data yang sebelumnya telah disimpan. Jadi apabila terjadi kerusakan data maka pihak perusahaan dapat mengambil kembali data yang sebelumnya telah di back up. Rencana back up pada aplikasi ini disesuaikan dengan penggunaan aplikasi. Pada keadaan normal dan tidak banyak order lelang tender maka back up akan hanya dilakukan sebanyak 2 kali dalam 
sebulan. Tetapi apabila sedang banyak order lelang tender, maka back up akan dilakukan sebanyak 4 kali dalam sebulan. Cara memback upnya adalah dengan cara menyalin folder data dalam server ke folder lain yang telah dinamai tanggal dilakukan back upnya.

\section{Implementasi Program}

Aplikasi dikembangkan dengan menggunakan bahasa PHP, sedangkan untuk database menggunakan MySQL. Semua itu sesuai dengan keunggulan masing-masing fungsi dari MySQL dan bahasa pemrograman. Pada gambar berikut (gambar 9 - 12) ditampilkan beberapa contoh tampilan layar aplikasi.

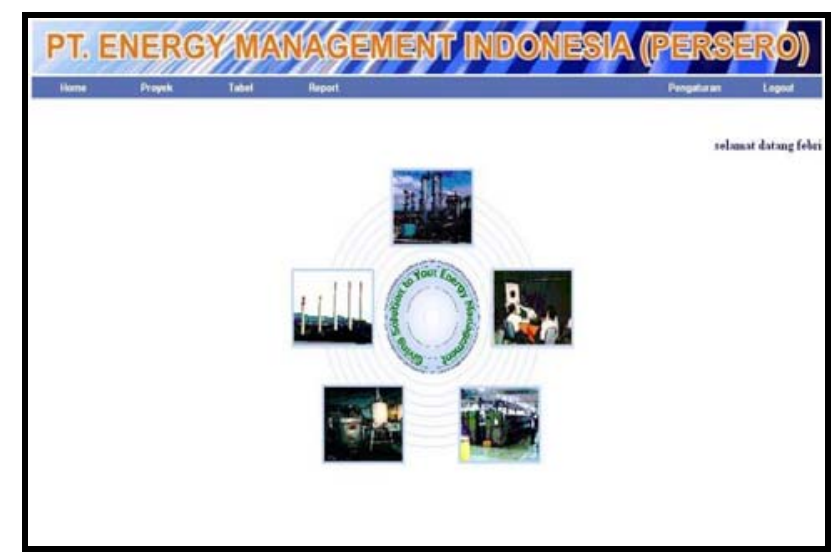

Gambar 9 Tampilan layar home

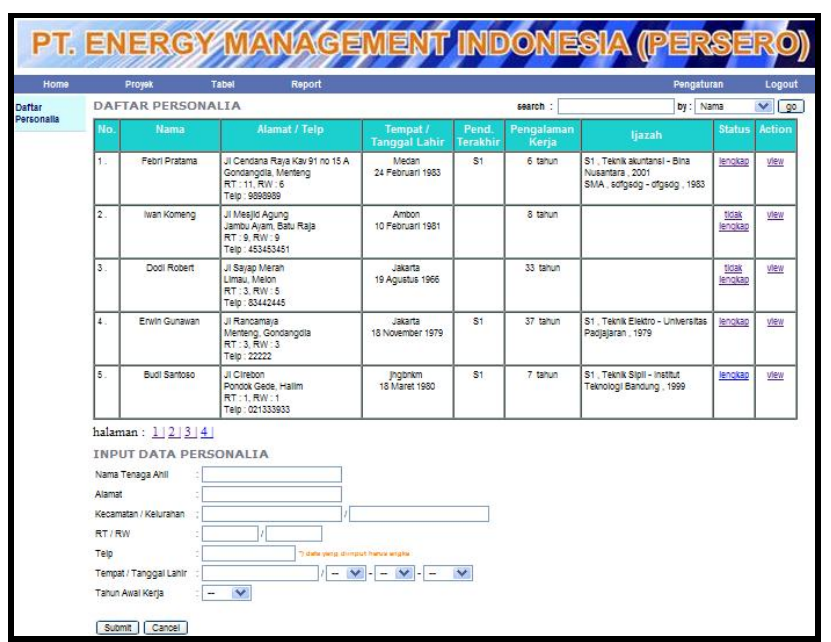

Gambar 11 Tampilan layar halaman daftar tenaga ahli

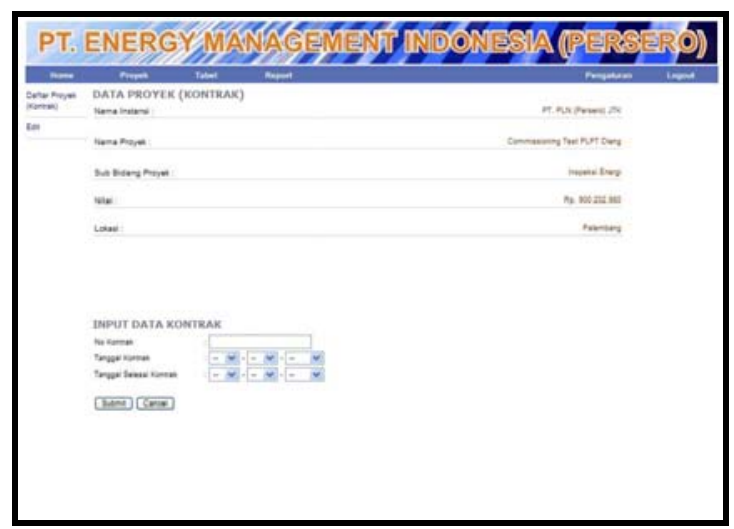

Gambar 10 Tampilan layar history kontrak proyek

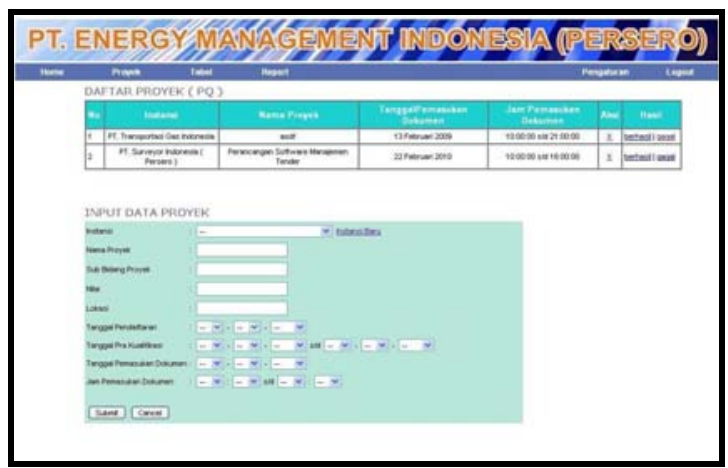

Gambar 12 Tampilan layar proyek prakualifikasi

\section{Evaluasi}

Evaluasi aplikasi dilakukan dengan dengan meminta masukan atau pendapat dari pengguna di PT. EMI. Untuk mengetahui lebih rinci, maka disebarkanlah kuesioner kepada 30 orang pengguna aplikasi ini di PT EMI. Evaluasi ini dipergunakan sebagai masukan dan kritik untuk mengembangkan kinerja aplikasi ini agar dapat lebih sempurna di masa yang akan datang. Hasil evaluasi pengguna ini ditampilkan pada tabel 2 - 8 . 
Tabel 2 Pendapat pengguna dari tentang aplikasi manajemen tender pada PT. EMI

\begin{tabular}{ccrr}
\hline & Pilihan & Jumlah Orang & Persentase \\
\hline a. & Tidak bagus & 0 & $0 \%$ \\
\hline b. & Kurang bagus & 2 & $6,66 \%$ \\
\hline c. & Cukup bagus & 6 & $20 \%$ \\
\hline d. & Bagus & 20 & $66,66 \%$ \\
\hline e. & Sangat bagus & 2 & $6,66 \%$ \\
\hline & Jumlah & 30 & $100 \%$ \\
\hline
\end{tabular}

Tabel 3 Pendapat pengguna dari tentang aplikasi manajemen tender ini berguna dalam membantu pekerjaan

\begin{tabular}{clrr}
\hline & Pilihan & Jumlah Orang & Persentase \\
\hline a. & Tidak berguna & 1 & $3,33 \%$ \\
\hline b. & Kurang berguna & 2 & $6,66 \%$ \\
\hline c. & Cukup berguna & 3 & $10 \%$ \\
\hline d. & Berguna & 21 & $70 \%$ \\
\hline e. & Sangat berguna & 3 & $10 \%$ \\
\hline & Jumlah & 30 & $100 \%$ \\
\hline
\end{tabular}

Tabel 4 Pendapat pengguna dari tentang fasilitas dan fungsionalitas dari aplikasi manajemen tender pada PT. EMI

\begin{tabular}{rlrr}
\hline & Pilihan & Jumlah Orang & Persentase \\
\hline a. & Tidak bagus & 1 & $3,33 \%$ \\
\hline b. & Kurang bagus & 2 & $6,66 \%$ \\
\hline c. & Cukup bagus & 6 & $20 \%$ \\
\hline d. & Bagus & 21 & $70 \%$ \\
\hline e. & Sangat bagus & 0 & $0 \%$ \\
\hline & Jumlah & 30 & $100 \%$ \\
\hline
\end{tabular}

Tabel 5 Pendapat pengguna dari tentang kemudahan penggunaan aplikasi manajemen tender pada PT. EMI

\begin{tabular}{ccrr}
\hline & Pilihan & Jumlah Orang & Persentase \\
\hline a. & Tidak bagus & 0 & $0 \%$ \\
\hline b. & Kurang bagus & 1 & $3,33 \%$ \\
\hline c. & Cukup bagus & 14 & $46,66 \%$ \\
\hline d. & Bagus & 15 & $50 \%$ \\
\hline e. & Sangat bagus & 0 & $0 \%$ \\
\hline & Jumlah & 30 & $100 \%$ \\
\hline
\end{tabular}

Tabel 6 Pendapat pengguna dari tentang kecepatan dan kecepatan penyajian data aplikasi manajemen tender

\begin{tabular}{ccrr}
\hline & Pilihan & Jumlah Orang & Persentase \\
\hline a. & Tidak bagus & 0 & $0 \%$ \\
\hline b. & Kurang bagus & 3 & $10 \%$ \\
\hline c. & Cukup bagus & 3 & $10 \%$ \\
\hline d. & Bagus & 24 & $80 \%$ \\
\hline e. & Sangat bagus & 0 & $0 \%$ \\
\hline & Jumlah & 30 & $100 \%$ \\
\hline
\end{tabular}


Tabel 7 Pendapat pengguna dari tentang penggunaan bahasa dalam aplikasi manajemen tender pada PT. EMI

\begin{tabular}{ccrr}
\hline & Pilihan & Jumlah Orang & Persentase \\
\hline a. & Tidak sesuai & 0 & $0 \%$ \\
\hline b. & Kurang sesuai & 1 & $3,33 \%$ \\
\hline c. & Cukup sesuai & 5 & $16,66 \%$ \\
\hline d. & Sesuai & 24 & $80 \%$ \\
\hline e. & Sangat sesuai & 0 & $0 \%$ \\
\hline & Jumlah & 30 & $100 \%$ \\
\hline
\end{tabular}

Tabel 8 Pendapat pengguna dari tentang Tampilan aplikasi manajemen tender pada PT. EMI

\begin{tabular}{rcrr}
\hline & Pilihan & Jumlah Orang & Persentase \\
\hline a. & Tidak bagus & 0 & $0 \%$ \\
\hline b. & Kurang bagus & 6 & $20 \%$ \\
\hline c. & Cukup bagus & 15 & $50 \%$ \\
\hline d. & Bagus & 9 & $30 \%$ \\
\hline e. & Sangat bagus & 0 & $0 \%$ \\
\hline & Jumlah & 30 & $100 \%$ \\
\hline
\end{tabular}

Berdasarkan hasil isian kuesioner dapat ditarik kesimpulan menurut pengguna aplikasi yang dibuat sudah memenuhi syarat mulai dari kecepatan dan ketepatan penyajian data, penggunaan bahasa, kemudahan penggunaan aplikasi, tampilan, fasilitas dan fungsionalitas, dan berguna untuk pengerjaan dokumen proyek dan para pengguna aplikasi juga merasa cukup puas dengan aplikasi yang dibuat.

\section{SIMPULAN}

Berdasarkan hasil implementasi dan evaluasi kuesioner yang dilakukan dapat ditarik kesimpulan bahwa sistem aplikasi manajemen tender yang dihasilkan dapat membantu PT. Energy Management Indonesia dalam menyiapkan RKS untuk proses tender. Aplikasi ini pun memberikan kemudahan bagi para admin proyek pada PT. Energy Management Indonesia karena pengerjaan RKS menjadi jauh lebih mudah. Beberapa saran untuk pengembangan lebih lanjut antara lain memperbaiki tampilan pada aplikasi untuk membuat aplikasi ini menjadi lebih menarik dan lebih variatif. dengan fungsi-fungsi yang lebih baik lagi.

\section{DAFTAR PUSTAKA}

Connoly, T. (2002). Database Systems: A Practical Approach to Design, Implementation and Management (6th ed.). New York: Addison-Wesley.

Hall, J. A. (2001). Sistem Informasi Akuntansi. Jakarta: Salemba Empat.

O’Brien, J. A. (2004). Introduction to Information System: Essentials for the e-Business Enterprise (11th ed.). New York: McGraw-Hill Companies.

Pressman, R. S. (2001). Software Engineering: a Practitioner's Approach (5th ed.). New York: McGraw-Hill. 
Shneiderman, B. (1998). Designing The User Interface: Strategies for Effective Human- Computer Interaction (3rd ed.). New York: Addison-Weasley.

Turban , E., Reiner, R. K., Jr., Potter, R. E. (2003). Introduction to Information Technology (3rd ed.). John Wiley \& Sons, Inc. 